\title{
In Vitro Microtuberization of Potato (Solanum Tuberosum L.) Cultivar through Sucrose and Growth Regulator
}

\author{
K. Momena ${ }^{1}$, R. Adeeba ${ }^{1}$, H. Mehraj ${ }^{2}$, A.F.M. Jamal Uddin ${ }^{2 *}$, Saiful Islam ${ }^{3}$ and L. \\ $\operatorname{Rahman}^{1}$
}

Advanced Seed Research and Biotech Center, ACI Limited, Dhaka ${ }^{1}$

Dept. of Horticulture, Sher-e-Bangla Agricultural University, Dhaka ${ }^{2}$

University of Development Alternative, Dhaka, Bangladesh ${ }^{3}$

Corresponding author : jamal4@yahoo.com

\begin{abstract}
Microtubers which are produced in tissue culture have benefits for disease free potato production. As growth regulators and sucrose concentration affect the initiation and growth of microtuber, therefore, an experiment was conducted to discover the suitable growth supplement to produce disease free potato microtuber. Four potato cultivars viz. Granula, Daimond, Sarpoaxona and Lal Pakril with three different treatments viz. $T_{1}=8 \%$ Sucrose, $T_{2}=6 \%$ Sucrose $+4 \mathrm{mg} / \mathrm{L}$ Kinetin, $T_{3}=8 \%$ Sucrose $+4 \mathrm{mg} / \mathrm{L}$ Kinetin $+1 \mathrm{mg} / \mathrm{L}$ BAP were used for micro tuberization as supplement of Murashige and Skoog (MS) medium. Among tested cultivars, Diamond performed better compare to other three potato cultivars with treatment combination $T_{3}$. Maximum number of culture showing microtuber (56.0), explant formed microtuber (93.3\%), number of microtuber (2.7), average diameter (4.42 mm) and average weight (97.61 mg) were found from Diamond cultivar in $8 \%$ Sucrose $+4 \mathrm{mg} / \mathrm{L} \mathrm{Kinetin}+1$ $m g / L B A P$.
\end{abstract}

Key words: Potato cultivars, microtuberization, sucrose, kinetin and BAP

\section{Introduction}

Availability of quality tuber is the prerequisite for successful potato production. Small size and weight microtubers have advantages in terms of disease free, storage, transportation and mechanization (Kefi et al., 2000b; Kanwal et al., 2006). A number of research groups all over the world are trying to bring about this revolution (Gopal et al., 2004; Zhijun et al., 2005; Zhang, 2006). Degeneration of potato is generally occurred due to viral, fungal and bacterial diseases. In Vitro propagation of potato (Solanum tubersoum L.) is commonly used in production of disease free seed tubers (Roca et al., 1979; Ranalli et al., 1994). Micro tuberization depends on a range of factors including sucrose concentration, temperature, photoperiod, light intensity and cultivar (Coleman et al., 2001; Tugrul and Samanci, 2001; Hussey and Stacey 1984; Ortiz-Montiel and Lozoya-Saldana, 1987; Garner and Blake, 1989). Use of growth regulators on micro tuberization in potato (Palmer and Smith, 1969; Wang and Hu, 1982; Estrada et al., 1986; Vecchio et al., 1994) cause considerable variation. Cytokinin has been predominantly used for microtuber production (Wang and $\mathrm{Hu}$, 1982). Potato tissue culture in Bangladesh was introduced by Bangladesh Agriculture Research Institute (BARI) in 1985, which is a government research institute situated at Gazipur. To meet the increased demand of potato seeds and increased trend of potato production among the farmers, research on potato tissue culture flourished recent years in agricultural sector as it yielded satisfactory results in terms of large scale production of viruses and diseases free plantlets in short period of time. Government research institutes as well as few private organizations have come forward to facilitate and establish tissue culture laboratories to 
meet increasing demand, but the major problem faced by this new potato seed producing industries are lack of trained manpower, suitability of efficient microtuberization protocol, lack of collaboration with national and international research institutes and seed companies. Thus, the aim of this study was to find out proper growth supplement on MS media to produce disease free potato microtuber which could be used for commercial microtuberization.

\section{Materials and Method}

Healthy and disease-free explants (Sprouts) of potato (Solanum tuberosum L.) were used for this experiment which was carried out from January to April, 2014 in Advanced Seed Research and Biotech Center, ACI Limited, Dhaka; and supervised from Department of Horticulture, Sher-e-Bangla Agricultural University, Dhaka, Bangladesh. Four different potato cultivars viz. Granula, Daimond, Surfo-exona and Lalpakri1 were used for the experiment. Potato tubers were washed several times with detergent followed by several times rinsing with distilled water, then the tubers were soaked in $\mathrm{GA}_{3} 50 \mathrm{mg} / \mathrm{l}$ concentration for at least three hours, after that the tubers were dried well and kept in dark room with humidity till the sprouting started. One-week old healthy sprouts were taken and washed with a few drop of detergent and then washed in running tap water for at least 30 minutes. Then the sprouts were taken to the laminar airflow for further sterilization to avoid any type of pathogenic contamination. At first the sprouts were washed with $70 \%$ ethanol for only 30 seconds then they were rinsed three times with autoclaved double distill water 15 minutes, then dipped in $0.1 \% \mathrm{HgCl}_{2}$ for $7 \mathrm{~min}$ and again five times rinsed with autoclaved double distill water for 25 minutes. Then the sprouts were put on the MS basal medium supplemented with $1.5 \mathrm{mg} / \mathrm{l} \mathrm{BAP}$ and $0.5 \mathrm{mg} / \mathrm{l}$ $\mathrm{GA}_{3}$ for shoot initiation. After 4 weeks, buds sprouted into full plantlet having 7-8 nodes. Single node cuttings were excised and inoculated on MS basal medium supplemented with 4mg/l BAP for further in vitro multiplication. The process was continued until complete plantlets were obtained in sufficient numbers. Four-weeks old plantlets were excised into shoot apices and nodal cuttings, which were used as explants. One apical explant was inoculated on medium in each culture tube and 4-5 multi nodal explants were inoculated in jars. 10 test tubes and 10 jars were prepared in such a way. Three different treatments viz. $\mathrm{T}_{1}=8 \%$ Sucrose, $\mathrm{T}_{2}=6 \%$ Sucrose $+4 \mathrm{mg} / \mathrm{L}$ Kinetin, $\mathrm{T}_{3}=8 \%$ Sucrose +4 $\mathrm{mg} / \mathrm{L}$ Kinetin $+1 \mathrm{mg} / \mathrm{L}$ BAP were used for micro tuberization. So for each concentration 10 replicates were prepared. Data was taken on number of microtuber formation, percentage of microtuber formation, days to microtuber induction, average diameter and average weight. After 10 weeks of incubation, microtubers were harvested in pre-weighed and sterilized polypropylene bags aseptically and their diameter and fresh weight was recorded.

\section{Results}

\section{Number of microtuber formation}

Different hormonal combinations showed variation in microtuber formation (Figure 1). Treatment $T_{3}$ revealed maximum number of microtuber (53.0, 56.0, 31.0 and 53.0 for Granula, Diamond, Sarpoexona and Lal Pakril respectively) followed by treatment $T_{2}$ (49.0, 52.0, 42.0 and 48.0 for Granula, Diamond, Sarpoexona and Lal Pakri1 respectively) while minimum number of microtuber observed in case of $\mathrm{T}_{1}(45.0,40.0,35.0$ and 39.0 for Granula, Diamond, Sarpoexona and Lal Pakri1 respectively) (Table 1).

\section{Percentage of microtuber formation}

Treatment $\mathrm{T}_{3}(8 \%$ Sucrose $+4 \mathrm{mg} / \mathrm{L}$ Kinetin $+1 \mathrm{mg} / \mathrm{L}$ BAP) presented highest percentage of microtuber $(88.3 \%, 93.3 \%, 51.7 \%$ and $88.3 \%$ for Granula, Diamond, Sarpoexona and Lal Pakri1 respectively) followed by $\mathrm{T}_{2}(81.7 \%, 86.7 \%, 70.0 \%$ and $80.0 \%$ for Granula, Diamond, Sarpoexona 
and Lal Pakri1 respectively). On the other hand, lowest percentage of microtuber observed from $\mathrm{T}_{2}$ $(66.7 \%, 75.0 \%, 58.3 \%$ and $65.0 \%$ for Granula, Diamond, Sarpoexona and Lal Pakri1 respectively) (Table 1).

Table 1. Response of growth supplements on number of microtuber and percentage of explants formed microtuber

\begin{tabular}{|c|c|c|c|c|c|c|c|c|c|}
\hline \multirow[b]{2}{*}{ Treatments } & \multirow[b]{2}{*}{$\begin{array}{l}\text { No. of } \\
\text { cultured } \\
\text { explants }\end{array}$} & \multicolumn{4}{|c|}{ No. of microtuber forming culture } & \multicolumn{4}{|c|}{$\%$ of explants formed microtuber } \\
\hline & & & 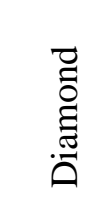 & 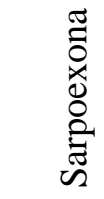 & 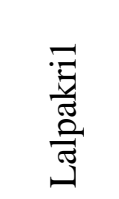 & 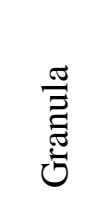 & 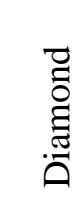 & 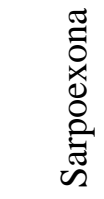 & 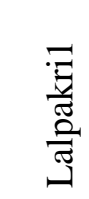 \\
\hline $\mathrm{T}_{1}$ & 60.0 & 40.0 & 45.0 & 35.0 & 39.0 & 66.7 & 75.0 & 58.3 & 65.0 \\
\hline $\mathrm{T}_{2}$ & 60.0 & 49.0 & 52.0 & 42.0 & 48.0 & 81.7 & 86.7 & 70.0 & 80.0 \\
\hline $\mathrm{T}_{3}$ & 60.0 & 53.0 & 56.0 & 31.0 & 53.0 & 88.3 & 93.3 & 51.7 & 88.3 \\
\hline
\end{tabular}

Here, $\mathrm{T}_{1}=8 \%$ Sucrose, $\mathrm{T}_{2}=6 \%$ Sucrose $+4 \mathrm{mg} / \mathrm{L}$ Kinetin, $\mathrm{T}_{3}=8 \%$ Sucrose $+4 \mathrm{mg} / \mathrm{L} \mathrm{Kinetin}+1 \mathrm{mg} / \mathrm{L}$ BAP

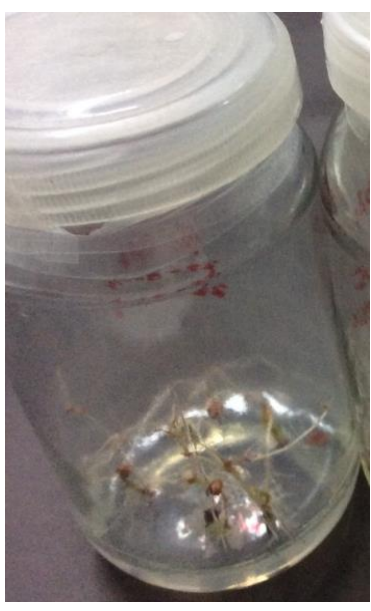

$\mathrm{T}_{1}=8 \%$ Sucrose

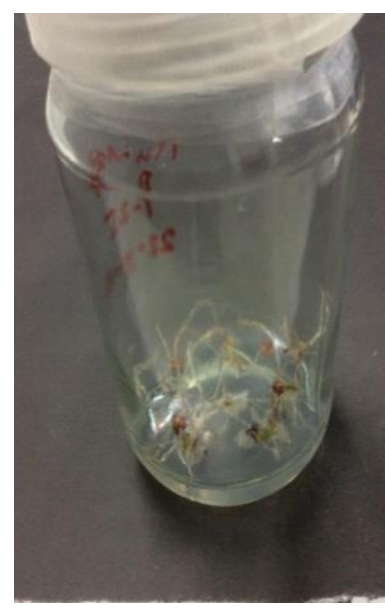

$\mathrm{T}_{2}=6 \%$ Sucrose $+4 \mathrm{mg} / \mathrm{L}$ Kinetin

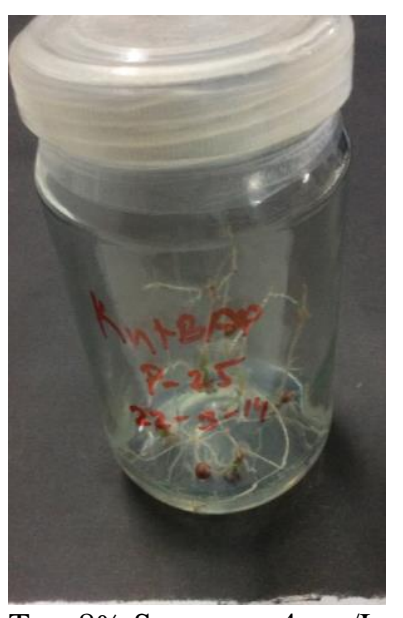

$\mathrm{T}_{3}=8 \%$ Sucrose $+4 \mathrm{mg} / \mathrm{L}$ Kinetin $+1 \mathrm{mg} / \mathrm{L}$ BAP

Figure 1. Formation of microtuber using growth hormones in different combinations

\section{Days to microtuber induction}

Early microtuber induction observed in treatment $\mathrm{T}_{3}(29.3,27.9,32.4$ and 29.7 days for Granula, Diamond, Sarpoexona and Lal Pakri1 respectively) and late was found from $\mathrm{T}_{1}(49.2,46.2,53.2$ and 49.8 days for Granula, Diamond, Sarpoexona and Lal Pakri1 respectively) while treatment $T_{2}$ showed medium.

\section{Number of microtuber}

Maximum number of microtuber was found from MS $+8 \%$ Sucrose $+4 \mathrm{mg} / \mathrm{L}$ Kinetin $+1 \mathrm{mg} / \mathrm{L}$ BAP $\left(\mathrm{T}_{3}\right)(2.3,2.7,2.0$ and 2.2/culture for Granula, Diamond, Sarpoexona and Lal Pakri1 respectively) followed by MS $+6 \%$ Sucrose $+4 \mathrm{mg} / \mathrm{L}$ Kinetin $\left(\mathrm{T}_{2}\right)(1.5,1.9,1.1$ and 1.5/culture for Granula, Diamond, Sarpoexona and Lal Pakri1 respectively) while minimum from MS + 8\% Sucrose $(0.9,1.1$, 0.5, 0.9/culture for Granula, Diamond, Sarpoexona and Lal Pakri1 respectively) (Table 2). 
Table 2. Response of growth supplements on days to microtuber induction and number of microtuber of potato

\begin{tabular}{|c|c|c|c|c|c|c|c|c|}
\hline \multirow[b]{2}{*}{ Treatments } & \multicolumn{4}{|c|}{ Days to microtuber induction } & \multicolumn{4}{|c|}{ Number of microtuber } \\
\hline & 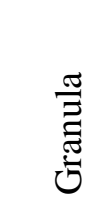 & 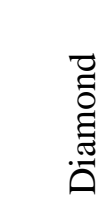 & 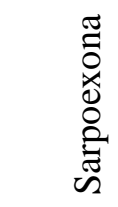 & 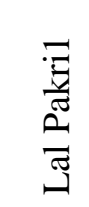 & $\frac{\widetilde{3}}{\vec{\Xi}}$ & 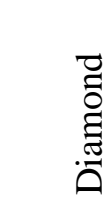 & 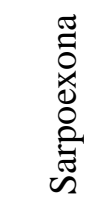 & $\begin{array}{l}\bar{\Xi} \\
\bar{\sigma} \\
\bar{\sigma} \\
\bar{\sigma}\end{array}$ \\
\hline $\mathrm{T}_{1}$ & 49.2 & 46.2 & 53.2 & 49.8 & 0.9 & 1.1 & 0.5 & 0.9 \\
\hline $\mathrm{T}_{2}$ & 38.7 & 36.4 & 44.6 & 39.1 & 1.5 & 1.9 & 1.1 & 1.5 \\
\hline $\mathrm{T}_{3}$ & 29.3 & 27.9 & 32.4 & 29.7 & 2.3 & 2.7 & 2.0 & 2.2 \\
\hline
\end{tabular}

Here, $\mathrm{T}_{1}=8 \%$ Sucrose, $\mathrm{T}_{2}=6 \%$ Sucrose $+4 \mathrm{mg} / \mathrm{L}$ Kinetin, $\mathrm{T}_{3}=8 \%$ Sucrose $+4 \mathrm{mg} / \mathrm{L}$ Kinetin $+1 \mathrm{mg} / \mathrm{L}$ BAP

\section{Average diameter}

Maximum average diameter was found from MS $+8 \%$ Sucrose $+4 \mathrm{mg} / \mathrm{L}$ Kinetin $+1 \mathrm{mg} / \mathrm{L}$ BAP (4.10, 4.42, 3.00 and $3.89 \mathrm{~mm}$ for Granula, Diamond, Sarpoexona and Lal Pakri1 respectively) followed by MS + 6\% Sucrose $+4 \mathrm{mg} / \mathrm{L}$ Kinetin $(3.08,3.55,2.22$ and 3.43 for Granula, Diamond, Sarpoexona and Lal Pakri1 respectively $\mathrm{mm}$ ) while minimum from MS + 8\% Sucrose (3.10, 3.54, 2.18 and $3.38 \mathrm{~mm}$ for Granula, Diamond, Sarpoexona and Lal Pakri1 respectively) (Table 3 and Figure 2).

\section{Average weight}

Maximum average weight was found from MS $+8 \%$ Sucrose $+4 \mathrm{mg} / \mathrm{L}$ Kinetin $+1 \mathrm{mg} / \mathrm{L}$ BAP $(93.47$, 97.61, 73.26 and $87.69 \mathrm{mg}$ for Granula, Diamond, Sarpoexona and Lal Pakri1 respectively) followed by MS $+6 \%$ Sucrose $+4 \mathrm{mg} / \mathrm{L}$ Kinetin $(56.26,61.73,54.89$ and $55.26 \mathrm{mg}$ Granula, Diamond, Sarpoexona and Lal Pakril respectively) while minimum from MS $+8 \%$ Sucrose $(36.27,40.02,31.73$ and $34.41 \mathrm{mg}$ Granula, Diamond, Sarpoexona and Lal Pakri1 respectively) (Table 3).

Table 3. Response of growth supplements on average diameter and weight of microtuber of potato

\begin{tabular}{|c|c|c|c|c|c|c|c|c|}
\hline \multirow[b]{2}{*}{ Treatments } & \multicolumn{4}{|c|}{ Avg. diameter (mm) } & \multicolumn{4}{|c|}{ Avg. weight (mg) } \\
\hline & $\begin{array}{l}\frac{\pi}{\Xi} \\
\text { 节 }\end{array}$ & 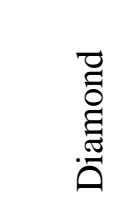 & 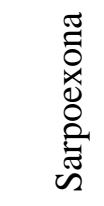 & 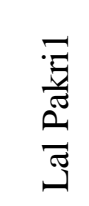 & 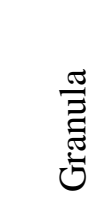 & 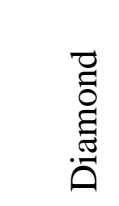 & 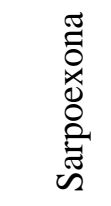 & 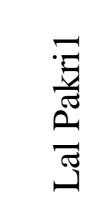 \\
\hline $\mathrm{T}_{1}$ & 3.10 & 3.54 & 2.18 & 3.38 & 36.27 & 40.02 & 31.73 & 34.41 \\
\hline $\mathrm{T}_{2}$ & 3.08 & 3.55 & 2.22 & 3.43 & 56.26 & 61.73 & 54.89 & 55.26 \\
\hline $\mathrm{T}_{3}$ & 4.10 & 4.42 & 3.00 & 3.89 & 93.47 & 97.61 & 73.26 & 87.69 \\
\hline
\end{tabular}

Here, $\mathrm{T}_{1}=8 \%$ Sucrose, $\mathrm{T}_{2}=6 \%$ Sucrose $+4 \mathrm{mg} / \mathrm{L}$ Kinetin, $\mathrm{T}_{3}=8 \%$ Sucrose $+4 \mathrm{mg} / \mathrm{L}$ Kinetin $+1 \mathrm{mg} / \mathrm{L}$ BAP 


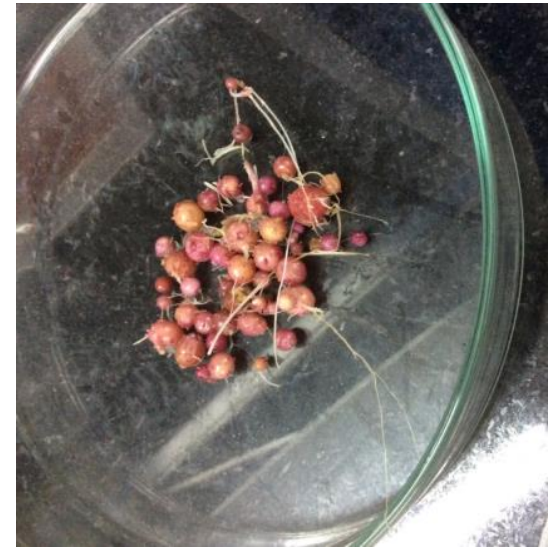

Figure 2. Harvested microtuber of potato

\section{III.Discussion}

Potato cultivars have diverse potential in microtuber production (Al-Safadi et al., 2000; Gopal et al., 1998) which have been further confirmed by this experiment as potato variety Daimond showed adequate response against treatment $8 \%$ Sucrose $+4 \mathrm{mg} / \mathrm{L}$ Kinetin $+1 \mathrm{mg} / \mathrm{L}$ BAP in MS medium. Kinetin has positive effect on microtuberization. Simko (1993) reported the effect of kinetin on microtuberization, which is due to its relationship with ethylene biosynthesis. Apart from sucrose and treatment combinations, effect of phytohormone on microtuberization also depends on plant genotype and or variety and amount of sucrose in culture medium as reported by Romanov et al. (2000) and Kefi et al. (2000a). Furthermore, Kinetin increases microtuber number because of its positive effect on cell elongation and tuberization (Romanov et al., 2000). In this study, $4 \mathrm{mg} / \mathrm{L}$ Kinetin in combination with sugar and BAP produced highest number of microtuber for potato variety Daimond. On the other hand, the role of BAP was on microtuber weight, which is also observed by Amina et al. (2006) and Anjum and Villiers, (1997). But kinetin produces no significant change on tuber size (Romanov et al., 2000) also on growth, diameter and weight of microtuber (Kefi et al., 2000a) because BAP plays crucial role on growth and weight. Size and weight of microtuber are related (Liu and Xie, 2001) which may be achieved by suitable combination of kinetin and BAP. However, BAP has greater potential for microtuberization than kinetin; and effect on reduction of total sugar and subsequently have increased starch content (Sarkar et al., 2006). Considering the potential of microtuberization of potato as revealed in this experiment, further study by various treatment combinations with kinetin and BAP including sugar for other potato cultivars of Bangladesh might result into a suitable protocol for commercial microtuberization of potato.

\section{Conclusion}

Four different potato cultivars and three treatment combination with sucrose and growth regulators that were used in this experiment revealed significant source of variation for potato microtuberization. The cultivar that exhibited best microtuberization was Diamond; and treatment $\mathrm{T}_{3}$ (8\% Sucrose +4 $\mathrm{mg} / \mathrm{L}$ Kinetin $+1 \mathrm{mg} / \mathrm{L}$ BAP) was most potential for potato microtuberization compare to other treatments of this experiment. 


\section{References}

Al-Safadi, B., Ayyoubi, Z. and Jawdat, D. (2000). The effect of gamma irradiation on potato microtuber production in vitro. Plant Cell, Tissue and Organ Culture 61: 183-187.

Amina Kanwal, A. A. and Shoaib, K. 2006. In vitro microtuberization of potato (Solanum tuberosum L.) cultivar Kuroda-a new variety in Pakistan. International J. Agriculture and Biol. 8: 337-340.

Anjum, M. A. and Villiers, T. A. (1997). Induction of microtubers in vitro from stem segments of Solanum tuberosum L. S. commersionii Due and S. acaule Bitt. Scientia Horticulturae 70: 231235.

Coleman, K. W., Danielle, J. D. and Colleman, S. E. (2001). Potato microtuber as research tools: A Review. Am J Potato Res. 78: 47-55.

Estrada, R., Tover, P. and Dodds, J. H. (1986). Induction of in vitro tubers in a broad range of potato genotypes. Plant Cell Tissue Org. Cult. 7: 3-10.

Garner, N. and Blake, J. (1989). The induction and development of potato microtubers in vitro on media free of growth regulating substances. Ann Bot. 63: 663-674.

Gopal, J., Chamail, A. and Sarkar, D. (2004). In vitro production of microtubers for conservation of potato germplasm: effect of genotype, Abscisic acid and sucrose. In vitro cell, Dev. Biol. Pl. 40: 486-490.

Gopal, J., Minocha, J. L. and Dhaliwal, H. S. (1998). Microtuberization in potato (Solanum tuberosum L). Plant Cell. Rep. 17: 794-798.

Hussey, G. and Stacey, N. J. 1984. Factors affecting the formation of in vitro tubers of potato (Solanum tuberosum L.). Ann Bot. 53: 565-578.

Kanwal, A., Ali, A. and Shoaib, K. (2006). In vitro microtuberization of potato (Solanum tubersoum L.) cultivar Kuroda- A new variety in Pakistan. Int. J. of Agri. \& Biol. 8(3), 337-340.

Kefi, S., Pavlista, A. D., Meagher, M. M. and Read, P. E. (2000b). Invertase activity as affected by cytokinin like compounds during potato tuberization In Vitro. Am. J. Potato Res. 77: 57-61.

Kefi, S., Pavlista, A. D., Read, P. E. and Kachman, S. D. (2000a). Comparsion of thidiazuron and two nitroguanidines to kinetin on potato microtuberization in vitro under short and long days. Plant Growth Regul. 19: 429- 436.

Liu, J. and Xie, C. (2001). Correlation of cell division and cell expansion to potato microtuber growth in vitro. Plant Cell, Tissue and Organ Culture, 67: 159-164.

Ortiz-Montiel, G. and Lozoya-Saldana, H. 1987. Potato minitubers: technology validation in Mexico. Am Potato J. 64: 535-544.

Palmer, C. E. and Smith, O. E. 1969. Cytokinins and tuber initiation in potato Solanum tuberosum L. Nature, 221: 279-280.

Ranalli, P., Bassi, F., Ruaro, G., Del Re, P., Dicandilo, M. and Mandolino, G. (1994). Microtuber and minituber production and field performance compared with normal tubers. Potato Res 37: 383391

Roca, W. M., Bryan, J. E. and Roca, M. R. (1979). Tissue culture for international transfer of potato genetic resources. Am. Potato. J. 56: 1-10.

Romanov, G. A., Aksenova, N. P., Konstantinova, T. N., Golyanovskaya, S. A., Kossomann, J. and Willmitzer, L. (2000). Effect of indole -3-acetic acid and kinetin on tuberization parameters of different cultivars and lines of potato in vitro. Plant Growth Reg. 32: 245-251.

Sarkar, D., Pandey, S. K. and Sharma, S. (2006). Cytokinins antagonize the jasmonates action on the regulation of potato tuber formation in vitro. Plant Cell, Tissue and Organ. Culture, 87: 285-295.

Simko, I. (1993). Effect of kinetin, paclobutrazol and their interactions on the micrituberization of potato stem segments cultured in vitro in the light. Plant Growth Reg. 12: 23-27.

Tugrul, S. and Samanci, B. (2001). Factors affecting tuber formation in potato (Solanum tubersoum L.). Potato Abstr. 26: 86.

Vecchio, V., Andrenelli, L., Pagano, M.T. and Benedettelli, S. (1994). Influence of photoperiod and media culture on potato microtuber production and dormancy (Abstr). Potato Res. 37: 440.

Wang, P. and $\mathrm{Hu}, \mathrm{C}$. (1982). In vitro mass tuberization and virus free seed potato production in Taiwan. Am. Potato J. 59:33-37 
Zhang, Z. J., Zhou, W. J., Li, H. Z., Zhang, G. Q., Sbrahmaniyan, K. and Yu, J. Q. 2006. Effect of jasmonic acid on In vitro explant growth and micro tuberization. Potato Biologia Plantarum 50(3): 453-456.

Zhijun, Z., Weijun, Z. and Huizhen, L. (2005). The role of GA, IAA and BAP in the regulation of In Vitro shoot growth and microtuberization in Potato. Acta. Physiol. 27: 363.

\section{Citation for this article (APA Style):}

Momena, K., Adeeba, R., Mehraj H., Jamal Uddin, A. F. M., Islam, S. \& Rahman L. (2014). In Vitro Microtuberization of Potato (Solanum Tuberosum L.) Cultivar through Sucrose and Growth Regulator. Journal of Bioscience and Agriculture Research 02(02), 76-82.

Retrieved December 10, 2014, from http://www.journalbinet.com/current-issue-jbar-1.html 